\title{
Re-shaping the Model of Economic Growth of the CEE Countries
}

\author{
Elena Makrevska Disoska \\ Faculty of Economics, \\ Ss. Cyril and Methodius University in Skopje \\ Blvd. Goce Delchev 9V, \\ Skopje 1000, Republic of Macedonia \\ E-mail: elenam@eccf.ukim.edu.mk
}

\begin{abstract}
The goal of this paper is to stress the importance of changing the present growth strategy of Central and Eastern European (CEE) economies. The economic model of resource and debt intensive growth they have enjoyed in the past two decades have proved to be ineffective and unsustainable. Given that the CEE growth model cannot be identified separately from the $E U$ as a whole, we try to propose possible policy measures that would stimulate growth in the CEE in context of the policies at the EU level.
\end{abstract}

Keywords: Central and Eastern Europe, demand, economic growth, sustainability, wage share

\section{Introduction}

Like most regions in the world, the CEE region has struggled to stimulate economic growth since the crisis. The growth model has proved to be ineffective and unsustainable. At the same time, it has not ensured nominal and real convergence towards EU-15 levels. The main goal of this paper is to identify the sources of growth, and at the same time the sources of imbalances of the growth model of the CEE countries, and to propose measures for its re-shaping.

We support the 'alternative' policy approaches (Podkaminer, 2013; Römisch, 2015) that are based on the central idea in the post-Keynesian / post-Kaleckian demand-led growth model developed by Bhaduri and Marglin (1990). This model 
states that high real wage is beneficial as it generates high effective demand against the orthodox view that high labor cost discourages production (Lavoie \& Stockhammer, 2012; Onaran \& Galanis, 2012; Cynamon \& Fazzari, 2015).

Podkaminer (2013) and Lissowska (2014) supported the argument that real unit labor costs were, in principle, negative in post-transition countries, meaning the growth of labor costs only partly covered growth in labor productivity. This shows that CEE countries were using the so-called 'wage moderation strategy'. This gap was substantially larger for some countries (Poland, Romania, Slovenia) than for the EU-15 in the period before the financial crisis.

Policymakers expected that reducing the share of wages in national income and raising the share for profits would reduce consumption, but they also expected investment and net exports to rise. Exports and imports depend on relative prices, which are functions of unit labor costs, so they reasoned that restraining wages would restrain labor costs and benefit exports. However, the tradeinduced effects on economic growth also depend on the degree of openness of the economy and price elasticity of exports and imports (Stockhammer, 2015).

The lower domestic consumption due to the lower wages was financed by a huge inflow of foreign capital and loans since the 1990s, as the European Union's newer members, primarily CEE countries, opened financial markets to foreign capital. This externally financed growth based on low wages is also known as debt-led growth. With the beginning of the crisis, the economic growth model of the CEE countries which was based on resource-intensive and debtintensive growth turned out to be ineffective and only contributing to short-term growth. The external liberalization was one of the most important pillars of the macroeconomic model which turns out to be the source of problems of external imbalances, bubbles driven by capital inflows and resulting growth instabilities. This would mean that the crisis showed that the model used during the EU accession process turned out to be unstable and cannot support further growth of these countries.

Still, the main adjustment tool in the crisis management strategy of the EU has been continuity of the wage reduction policy for most of the CEE countries. Internal devaluation policy is pushed by direct intervention into wage development by cutting and freezing public sector and minimum wages, particularly in Hungary, Latvia and Romania. Structural reforms also go to the direction of downward pressure on wages. We believe these policies are not addressing the real cause and instead are creating harmful side-effects since these countries have no costcompetitiveness problem and have room for upward wage convergence. 
The focus of this paper are countries usually referred to as new EU memberseleven countries from Central and Eastern Europe that became EU members with successive enlargements in 2004, 2007 and 2013 - the Czech Republic, Estonia, Hungary, Latvia, Lithuania, Poland, Slovakia, Slovenia, Bulgaria, Romania and Croatia. For the sake of clarity we will refer to this group of countries as the CEE countries.

In order to fulfill the goal of this paper, our analysis is based on the AMECO database. The lack of long time-series limited the possibility of using econometric model in the paper, and therefore we used graphs and tables for illustration.

The paper is structured as follows: the second chapter gives background of the growth performance of the CEE countries and convergence to the EU-15 levels. The third chapter reviews the use of the wage moderation strategy in the EU. The fourth chapter presents the variables that determine economic growth, except for government spending: consumption, investments and net export. At the end, it makes suggestions and recommendations to change the growth strategy of the CEE countries.

\section{Growth performance of the CEE countries and convergence to the EU-15 levels}

Central and Eastern European countries went through a painful process of economic transformation from central to market economies since the collapse of their previous regimes. The transformation was followed by EU integration, which was a strong incentive for economic convergence with the Western European countries, followed by political integration, liberalization of the markets, trade integration, financial integration and attraction of FDI and foreign savings (see among others, Becker et al., 2010; Bennett, Estrin \& Urga, 2007; Godoy \& Stiglitz, 2006; Falcetti, Lysenko \& Sanfey, 2006; Fidrmuc \& Tichit, 2009; Hare \& Turley, 2013; Kornai, 2006; Rusinova, 2007).

According to Figure 1, the rates of economic growth reached record high values of over 7 per cent during 2006 and 2007, due to the rates of over 10 per cent in the Baltic States and also the Slovak Republic. In the period 2008-2013, the rates of economic growth decreased in most of the CEE countries (except for Poland) as a result of the economic crisis. The average growth for the period 2008-2014 was only 0.51 per cent. 
Regarding the economic performance of the CEE countries compared with the EU levels, a recent paper investigating the growth effects of EU cohesion policy during the past decade has found that EU countries are converging, but with group and country variations in economic performances (Marzinotto, 2012). The real economic convergence is about diminishing differences in economic development levels. Therefore, the countries at lower economic development level need to grow faster than the developed ones in order to close the welfare gap.

Figure 1. Annual GDP growth of CEE countries, $\%$

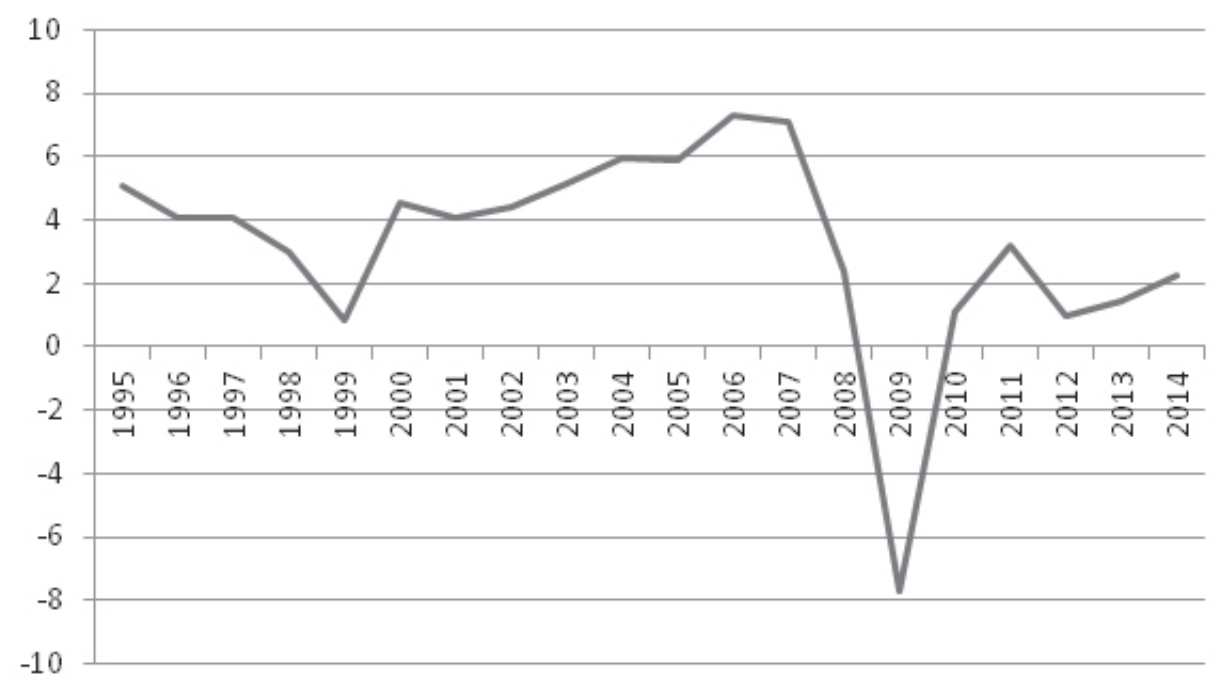

Source: World Bank development indicators

The driver of the convergence process was technology transfer, which enabled product quality upgrading, better organizational structures and practices. Due to the removed cross-border barriers, foreign trade and direct investments enabled technology transfer and spillovers. Financial markets were also opened up to foreign financial institutions. Foreign banks attained dominant market positions in most countries of the region. Most of the banking systems were bought up by Western European banking groups. There were huge net capital inflows before the crisis, larger than in any other emerging or developing regions (Becker et al., 2010).

The nominal convergence does not show significant progress towards the growth performance of the EU countries. According to the indicator GDP annual growth rate of CEE countries, presented in Table 1, growth performances (weighted 
average) have not be very impressive. The growth difference with respect to the EU-28 is 1.43 percentage points (p.p.) during 1995-2014. Over 2 p.p. differences were achieved only in the period before the crisis (1995-2007) when CEE economies experienced significantly higher growth than Western European countries as a consequence of their lower starting point. Due to the crisis in the period 2008-2014 the rates of economic growth decreased in most of the CEE countries (Table 1$)$. Still, the nominal convergence rate remained positive $(0.25$ p.p.) due to the positive rates of economic growth in Poland and Slovakia.

Table 1. Nominal convergence rate in percentage points in different periods of time (annual GDP growth)

\begin{tabular}{|l|c|c|c|}
\hline & $\begin{array}{c}\text { Before the } \\
\text { crisis }\end{array}$ & $\begin{array}{c}\text { After the } \\
\text { crisis }\end{array}$ & $\begin{array}{c}\text { The whole } \\
\text { analyzed period }\end{array}$ \\
\hline Bulgaria & 3.597 & $\mathbf{2 0 0 8 - 2 0 1 4}$ & $\mathbf{1 9 9 5 - 2 0 1 4}$ \\
\hline Croatia & 4.136 & -1.549 & 2.670 \\
\hline Estonia & 3.642 & 0.373 & 2.042 \\
\hline Hungary & 7.324 & -0.138 & 2.498 \\
\hline Latvia & 3.239 & 0.087 & 4.575 \\
\hline Lithuania & 4.792 & 3.125 & 2.136 \\
\hline Poland & 3.495 & 1.149 & 4.208 \\
\hline Romania & 5.218 & 1.875 & 2.674 \\
\hline Slovak Republic & 4.327 & -0.523 & 4.048 \\
\hline Slovenia & 7.381 & -0.545 & 2.540 \\
\hline Czech Republic & 9.247 & 0.799 & 4.461 \\
\hline AVERAGE & 5.127 & 0.509 & 2.676 \\
\hline European Union & 2.558 & 0.125 & 3.139 \\
\hline Difference NMS-EU & & 0.384 & 1.707 \\
\hline ponvergence rate in & 2.569 & 1.432 \\
\hline
\end{tabular}

Source: World Bank data development indicators

Regarding the real convergence there are two main indicators: beta and sigma convergence (Barro \& Sala-i-Martin, 1995). Beta-convergence, as standard

Tallinn University of Technology (ISSN 2228-0588), Vol. 6, No. 2 (21) 
indicator for real convergence, shows that there is absolute convergence within the EU-28 (for the period 1995-2011) in the observed period (Dobrinsky \& Havlik, 2014, pp. 8-11). Respectively, the time necessary to move halfway to the balanced growth path corresponding to this speed of convergence is around 35 years. ${ }^{1}$ Due to the low rates of economic growth in 2012-2014 it is understandable that the convergence was not sped up.

Sigma-convergence shows that the main trend during the period 1995-2011 was towards a declining standard deviation of per capita income within the EU-28, especially in the period after 2000. Within the CEE economies, the pattern of the dispersion of per capita income was uneven: an initial rise in the second half of the 1990s was reversed in the following decade with a steady decline ever since. The average GDP per capita level in the CEE in 2014 reached 43.45 per cent of the EU average, compared with 20.7 per cent in 1995. Countries such as Estonia, Slovakia, Slovenia and Czech Republic reached over 55 per cent of the EU average (according to the World Bank database).

\section{Use of the wage moderation strategy}

Wage moderation as an economic growth strategy is ambiguously defined in the literature. Blanchard (2000) applies the concept in an economy with a balanced growth path. Theory defines it as restraining the growth in average wages below growth in productivity. The tendency toward wage repression in the EU was set in 1975. This so-called post-war economic system adopted in the major continental European countries was "borrowed" from the UK and USA and included progressing internal and external liberalization, wholesale privatizations, unleashing of the financial sectors, the 'taming' of the trade unions, labor market 'flexibilization' and successive rounds of 'reforms' contracting the welfare state institutions. The war against high imported inflation was eventually won by application of high interest rates. The years 1974-1975 also mark the end to the post-war full-employment era. Netherlands and Ireland were the first countries that used the strategy to reverse an upward trend in unemployment, which was

1 The implied speed of convergence $(\beta)$ is calculated from the identity: $1-\mathrm{e}-\beta \mathrm{T}=\mathrm{b}$, where $T$ stands for the duration of the period covered by the regression. Note that in the framework of the Solow growth model $\beta$ refers to the speed of convergence to steady state and not necessarily to the speed of convergence in per capita incomes (see below). The interpretation of $\beta$ is as follows: each year the economy moves $\beta \%$ of the remaining distance towards the steady state. E.g., the time $\tau$ it takes to move half way to the balanced growth path is calculated as: $\tau=-\ln (0.5) / \beta$. 
observed since the late 1960s. They were followed by France, Spain, Italy, and Germany in the late 1990s. International Monetary Fund (IMF) attributes wage moderation plus changes in labor policies and structural conditions to ending the upward trend in unemployment in those countries (Estevao \& Nargis, 2002). However, Blanchard (2000) attributes this evolution in wages and unemployment to erosion in European workers' bargaining power since the mid-1980s, and later literature also supports this argument.

Numerous studies confirmed that the EU as a whole exemplifies a wage-led economy (Stockhammer et al. (2009) for the euro area, Onaran and Obst (2015) for the EU-15, Onaran and Galanis (2012) for the euro area and other developed countries, Storm and Naastepad (2012), Onaran et al. (2011), Hein and Vogel (2008), Naastepad and Storm (2007) for Germany, Naastepad and Storm (2007) for France and Italy, and Bowles and Boyer (1995) for the UK).

Overall, a simultaneous 1 percentage point decline in wage share in all EU-15 countries leads to a 0.3 per cent decline in GDP among all EU-15 countries (Onaran \& Obst, 2015). The negative effect of the joint race to the bottom on growth ranges between 0.07 per cent in Ireland and 1.03 per cent in Greece. Therefore, the results are difficult to compare. Because of data insufficiencies, there is no empirical evidence about CEE countries. However, Podkaminer (2013) and Lissowska (2014) supported the argument that real unit labor costs were, in principle, negative in post-transition countries, meaning that growth of labor costs only partly covered growth in labor productivity. This gap was substantially larger for some countries (Poland, Romania and Slovenia) than for the EU-15 in the period before the financial crisis.

The data show that the average share of wages as a percentage of GDP peaked at 65 per cent in 1975 and declined to 55 per cent in the past decade for the EU-15 (Fig. 2). The decline is more moderate in Belgium, Denmark, and Luxembourg and relatively less in the UK. This decline has not enhanced economic growth rates. Growth has become anemic and irregular, and in the last decade, it has been below the average value of 2 percentage points. Although a decreasing wage share might be expected to enhance labor productivity and employment, evidence indicates otherwise. In 2013, the unemployment rate has reached its highest pick at 11.1 per cent. Even though in recent years the interest rate of the ECB and the inflation is low or even negative, the suppression of the wages is still present.

Regarding CEE, the wage share in GDP tends to be lower compared with EU15 and it also shows a downward trend. Figure 3 indicates that it has declined 
Figure 2. Average value of the adjusted wage share and annual GDP growth of EU-15, 1960-2016

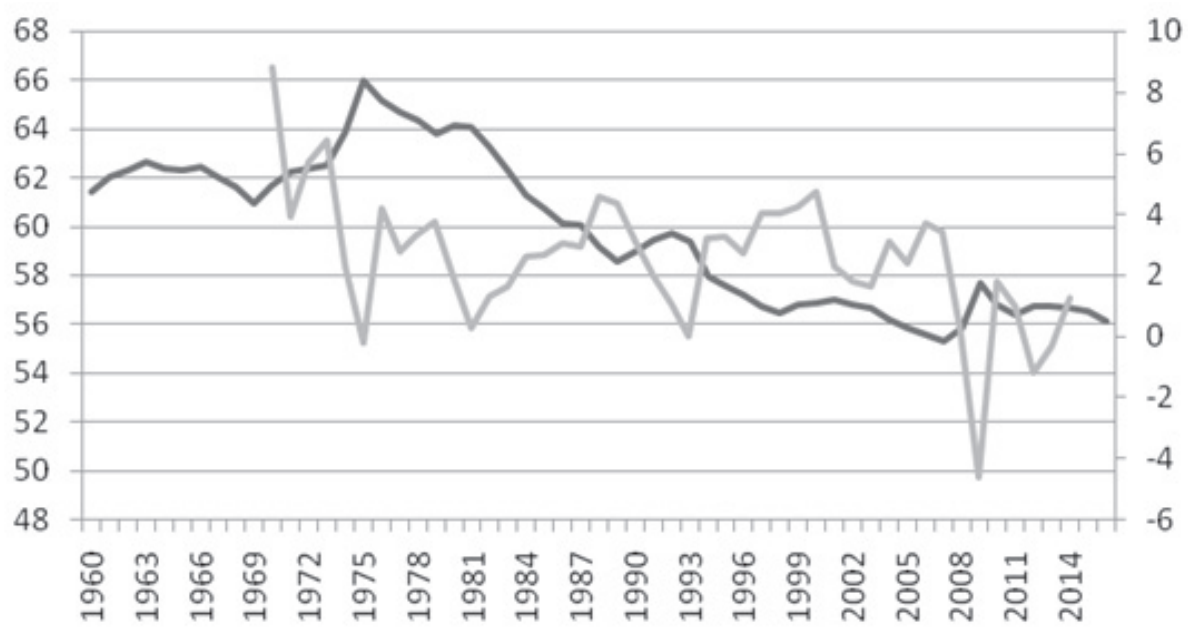

-wage share (left axis) G GDP (right axis)

Source: AMECO Database (item ALCDO, item UVGD, http://ec.europa.eu/economy_finance/ ameco/user/serie/ResultSerie.cfm)

Figure 3. Average value of the adjusted wage share and annual GDP growth of CEE countries, 1991-2016

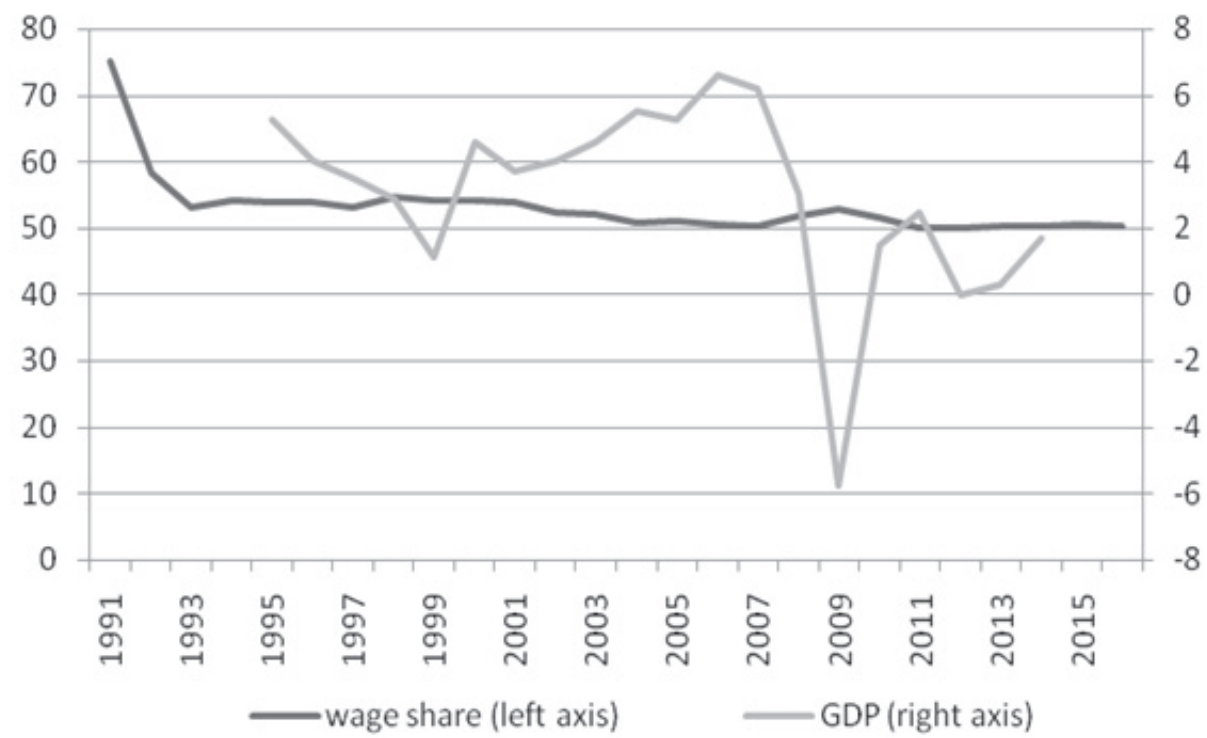

Source: AMECO Database (item ALCDO; item UVGD, http://ec.europa.eu/economy_finance/ ameco/user/serie/ResultSerie.cfm) 
from 60 per cent to approximately 50 per cent and flattened during the previous decade and longer. Wage share in Slovenia is higher than EU-15 and the Czech wage share increased significantly against the main trend. However, all CEE countries (except Bulgaria) had lower real wage growth than productivity.

According to the analysis of the World Bank from 1995 to 2009 (Cuaresma et al., 2012), CEE countries had the largest productivity gains in the whole EU, with productivity shooting up by 2.5 per cent in service industries and about 5 per cent in manufacturing (Table 2). Empirical analysis proves that CEE countries did far better than Western European economies on this account during the past two decades, as structural supply-side factors played a greater role in the CEE growth model (Dobrinsky \& Havlik, 2014, p. 22). Wage-adjusted productivity in manufacturing for CEEs is substantially higher than that in EU-15 or Germany. This 'productivity reserve' leaves room for upward wage convergence.

Table 2. Wage adjusted productivity in manufacturing in 2012 (1,000 euros per employed)

\begin{tabular}{|l|c|c|c|}
\hline Country & $\begin{array}{c}\text { Apparent labor } \\
\text { productivity* }\end{array}$ & $\begin{array}{c}\text { Average } \\
\text { personnel } \\
\text { costs }\end{array}$ & $\begin{array}{c}\text { Wage-adjusted } \\
\text { productivity }\end{array}$ \\
\hline EU-28 & 54.0 & 37.7 & 144.0 \\
\hline Czech Republic & 25.7 & 16.2 & 158.5 \\
\hline Hungary & 26.9 & 13.1 & 204.6 \\
\hline Greece & 38.1 & 25.6 & 149.1 \\
\hline Germany & 67.2 & 50.3 & 133.5 \\
\hline Poland & 22.2 & 11.8 & 187.4 \\
\hline Slovakia & 21.9 & 14.8 & 147.8 \\
\hline Romania & 11.5 & 6.2 & 184.7 \\
\hline
\end{tabular}

* Apparent labor productivity is defined as value added at factor costs divided by the number of persons employed.

Source: Eurostat, 2016 (NACE_Rev._2)

However the gap between the growth of compensation of employees and the growth of labor productivity in the pre-crisis period for the CEE was sustainably larger than the EU-15 countries, as shown in Figure 4, especially for Romania, Slovakia and Poland. This trend of higher productivity compared to the real 
wages in the CEE compared to the EU-15 is still present after the crisis but the gap is narrowing. Figure 4 shows that real labor productivity was higher than the real unit labor cost for 0.475 p.p., and after the crisis the gap narrowed to 0.133 p.p.

Figure 4. Cumulated change of labor productivity and of labor cost (initial year=1) in $2008 / 2000$ and $2013 / 2008$

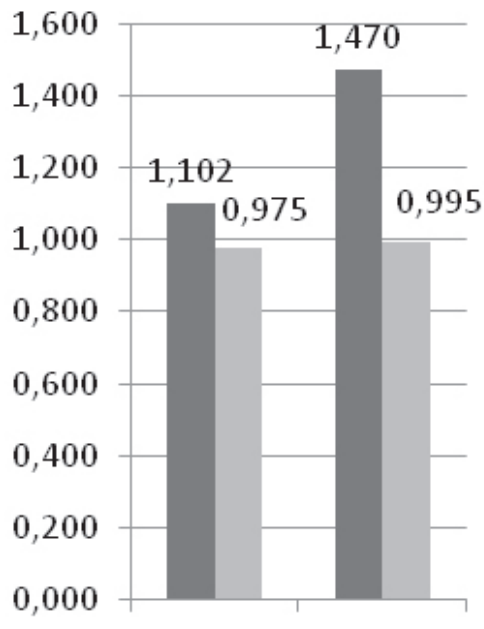

EU-15

CEE

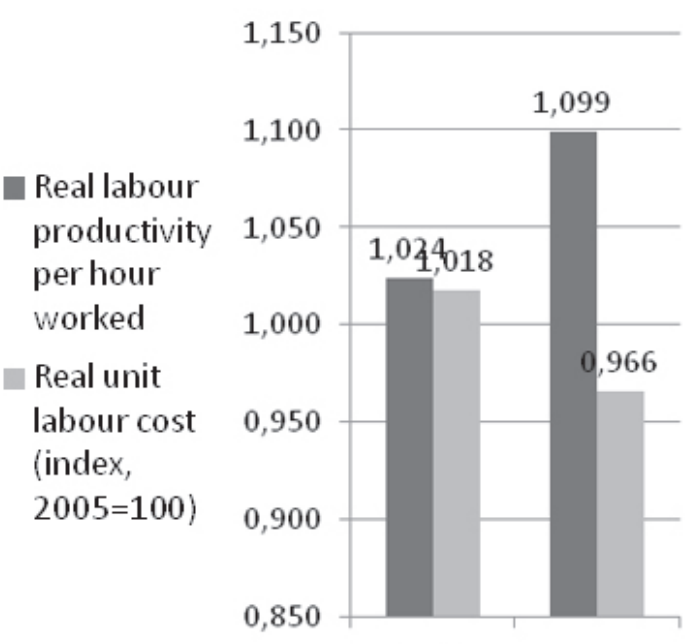

EU-15

CEE

Note: Change in unit labor costs corresponds to the change of compensation of employees per number of employees not covered by the change of labor productivity plus the change of the share of employees in total employment.

Source: Eurostat, 2015; 2016

One of the main concerns is that the working age population in the CEE nations is expected to decline by an average of 0.6 per cent a year between 2010 and 2030, while the population aged 65 and older is projected to rise at a 1.9 per cent annual rate. Under current trends, according to Labaye and others (2013), the effect of ageing on the labor force could reduce labor productivity and also per capita GDP by 0.7 per cent a year between 2010 and 2020 and 0.3 per cent a year between 2020 and 2030. This creates additional challenges and requires some changes in the model of economic growth. 


\section{The exposed weaknesses of the model of economic growth of the CEE countries}

The following chapter analyzes separately the consumption, investment and export of the CEE countries in order to identify flaws in the growth model.

\subsection{Consumption}

In the CEE countries, private consumption had positive tendencies in the period before the financial crisis (see Fig. 5). Availability of credit enabled by foreign financing institutions resulted in rapid growth in consumption until 2008. In the period after the crisis, private consumption in CEE countries started to grow but still has not reached the levels before the crisis.

Figure 5. Private consumption in CEE, growth rate per capita, \%

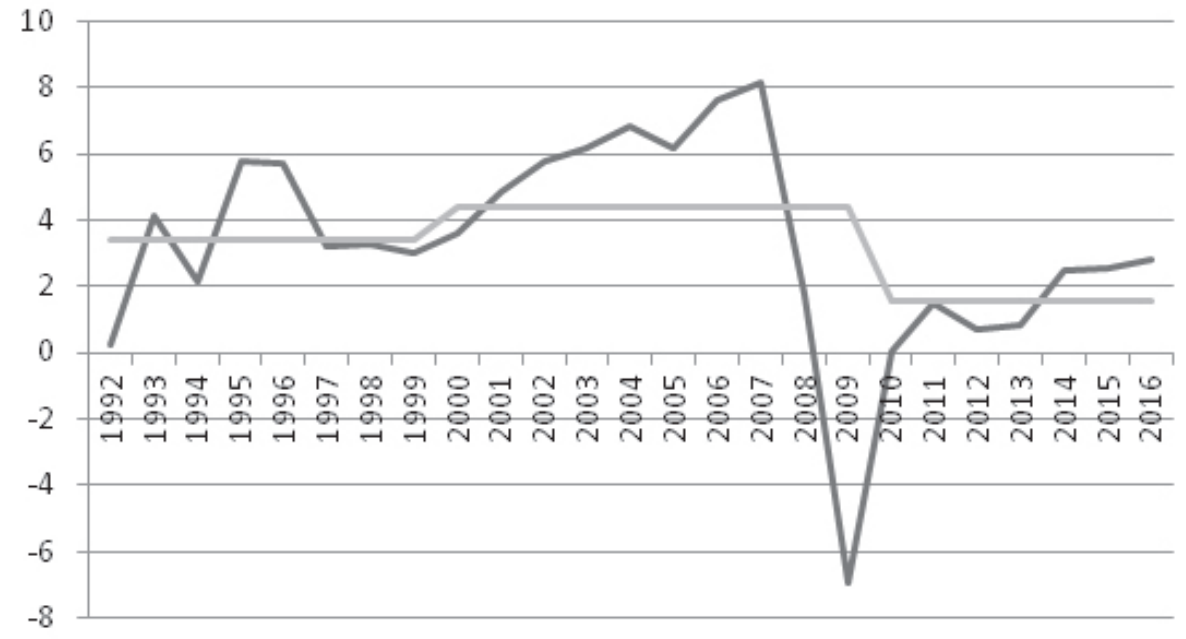

- growth rate

10 year average

Source: AMECO database (Item OCPH)

Tridico (2012) underlines the impact of decreasing trend of wages on the instability of growth. Namely, unstable jobs and poor wages in the framework of consumerism, in the USA as well as in Europe, encouraged households to borrow. This helped to sustain consumption, but at the price of instability. According to the analysis by Leitner and Römisch (2015), on average, the CEE disposable income of households grew 0.5 p.p. per year slower than GDP per capita in the period from 1995 to 2011. 
The liberalization of most prices and the freedom to engage in trade during the process of transformation to market economies contributed to a higher rate of inflation. The initial inflation was not followed by increase in the wages and other regular household incomes (such as pensions) accordingly and this caused gigantic losses in real wages. With the accession to the EU, the countries felt additional pressure of decrease in the wage share due to the present policy of wage moderation in the EU.

In the absence of wage increase, the households increased their borrowings in order to maintain consumption levels. For example, the indebtedness of households in Lithuania increased 15 times in 2011 compared to 2001. On average, the indebtedness of households in CEE countries increased 5 times in 2011 compared to 2001 (Fig. 6).

Figure 6. Indebtedness of households in CEE countries, debt as percentage of disposable income

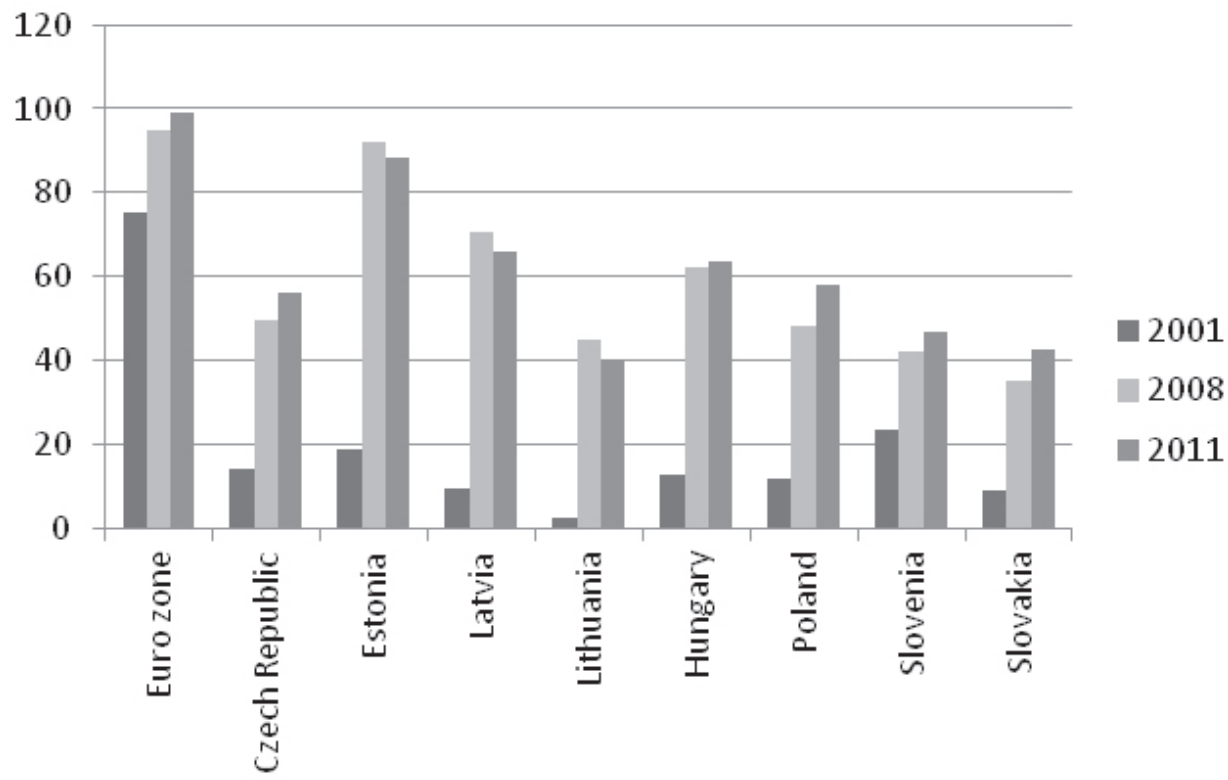

Source: Lissowska, 2014, p. 16

Credit boom was a result of two important factors: first, restructured banking and non-banking financial sectors which were largely placed in the ownership of foreign financial institutions, and second, improved access to international capital markets. The foreign banks that largely controlled the banking sectors in the region, and therefore kept the banks on board in the crisis, have been one of the region's biggest concerns. According to the European Bank for Reconstruction 
and Development (EBRD), in 2007, European banks (mainly Austrian, French, Italian, Dutch, German and Greek) owned 94 per cent of the banking system assets in Albania, 82 per cent in Bulgaria, 86 per cent in FYROM, 79 per cent in Montenegro, 87 per cent in Romania and 75 per cent in Serbia. The biggest fear was the Greek crisis, since Greece is present in the region with seven major Greek banks, among them National Bank of Greece, EFG Eurobank, Piraeus, and Alpha Bank. By 2007, Greek banks had accumulated a significant market share in the region, accounting for around 30 per cent of total banking assets in Macedonia, 25 per cent in Albania, 15 per cent in Serbia, where three out of ten banks were Greek (Panagiotou, 2012).

In the following, a correlation is made between the inflow of foreign credits and the indebtedness of households in CEE countries. Figure 7 shows that the increase of indebtedness correlates positively with the size of inflow of foreign credits to a given country.

Figure 7. Correlation between inflow of foreign credits as percentage of GDP and change of debt to income in p.p. in 2001-2008

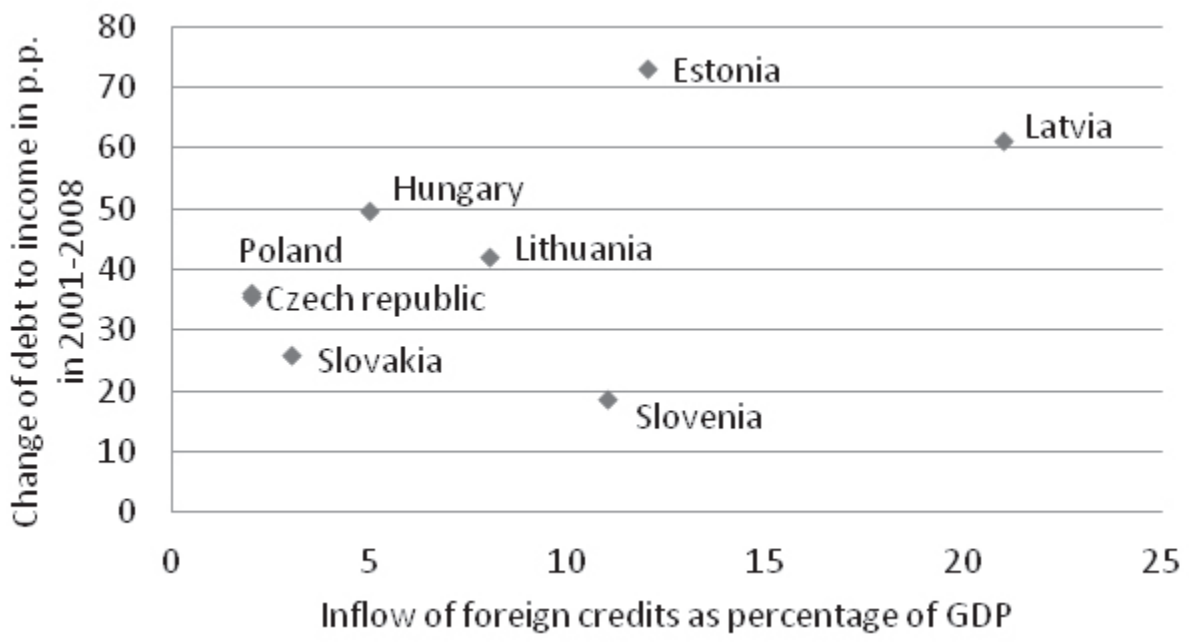

Source: Scatter made by the author, data from Lissowska, 2014, p. 16; Eurostat, 2015; 2016

This means that the main reason for fueling the growth of consumption was the inflow of credits in the years before the crisis (Lissowska, 2014). This trend is mostly evident for the countries in the upper right corner of Figure 8, such as Latvia, Estonia, Lithuania and Hungary. Lending was dominantly from Western European banks, which helped fuel domestic consumption and led to real estate bubbles in Bulgaria, Romania and Slovakia. Between 2000 and 2007, residential 
real estate prices rose by three and a half times in Bucharest, Romania, more than tripled in Bratislava, Slovakia and doubled in Sofia, Bulgaria (Labaye et al., 2013). With the beginning of the crisis and a sudden stop of foreign credits in 2009 , consumption declined by 10 per cent compared to the previous year, as seen in Figure 5.

Even though the funding decreased, the foreign banks did not exit the domestic economies and oriented towards domestic crediting. Luckily, this did not happen, and is most likely not going to happen in the near future. The first reason is that the banking sectors in the region are in relatively good shape (well-capitalized and profitable) and thus holding on to these portfolios is still attractive for foreign banks. Second, local portfolios are small relative to the size of foreign parent banks (i.e. selling them would make only a small contribution to the broader deleveraging process). Third, even where asset sales are being contemplated, it is likely to be difficult in this environment for foreign parents to find buyers for their local subsidiaries (Burgess, 2012).

\subsection{Investments}

The indicator gross capital formation as per cent from GDP had been increasing in the CEE countries until the beginning of the financial crisis (Fig. 8). After the crisis, the level of gross capital formation has flattened at the level of 20 per cent from GDP. This evidence, taken together with the average growth of GDP, indicates that high resilience on foreign capital inflows used by the CEE countries could not obtain real recovery and is proved to be unstable.

Figure 8. Gross capital formation in the CEE, \% of GDP

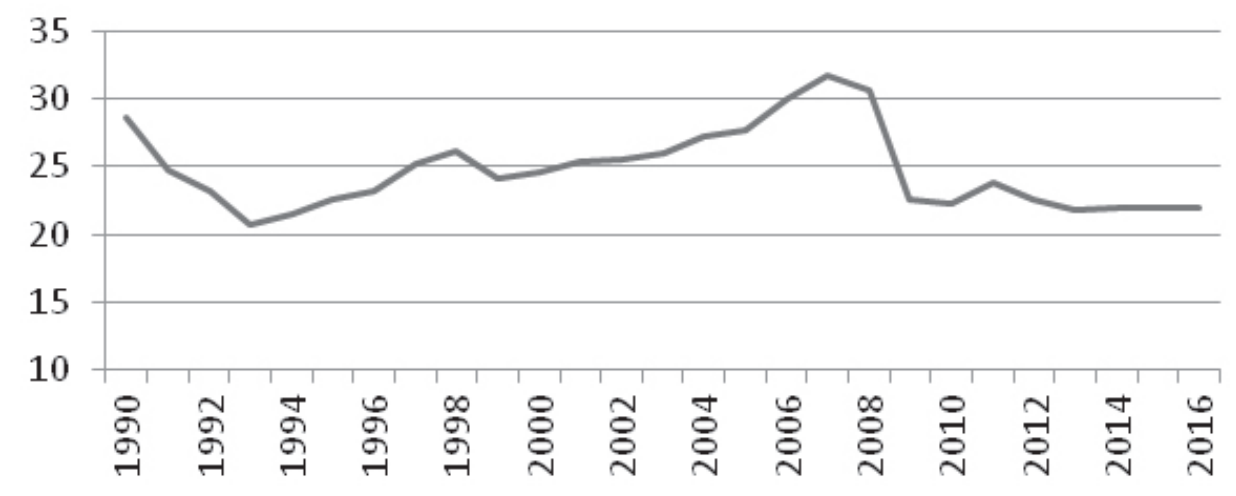

Source: AMECO database (items UITT and UVGD) 
Since at least 1995, overall savings have failed to cover investments. National saving rates varied from year to year, but on average stayed around 19 per cent of GDP, while investments were generally over 25 per cent of GDP. This is mainly due to the large current account deficits that will be discussed below. This situation has made the CEE economies dependent on foreign capital.

For most of the CEE countries, FDIs were the most important source of financing (Table 2), introducing technology, managerial know-how and skills required for restructuring companies (Popescu, 2014). For example, for Bulgaria in the period from 1995 until 2008, 44.63 per cent of the total gross fixed capital formation was a result of FDI which accounted for around 10 per cent annual growth of FDI as percentage of GDP (see Fig. 9). In addition, when the crisis hit, investment inflows - 80 per cent of which had originated in Western Europevirtually collapsed, and have only partially recovered (Labaye et al., 2013).

Figure 9. FDI inflows in the CEE countries

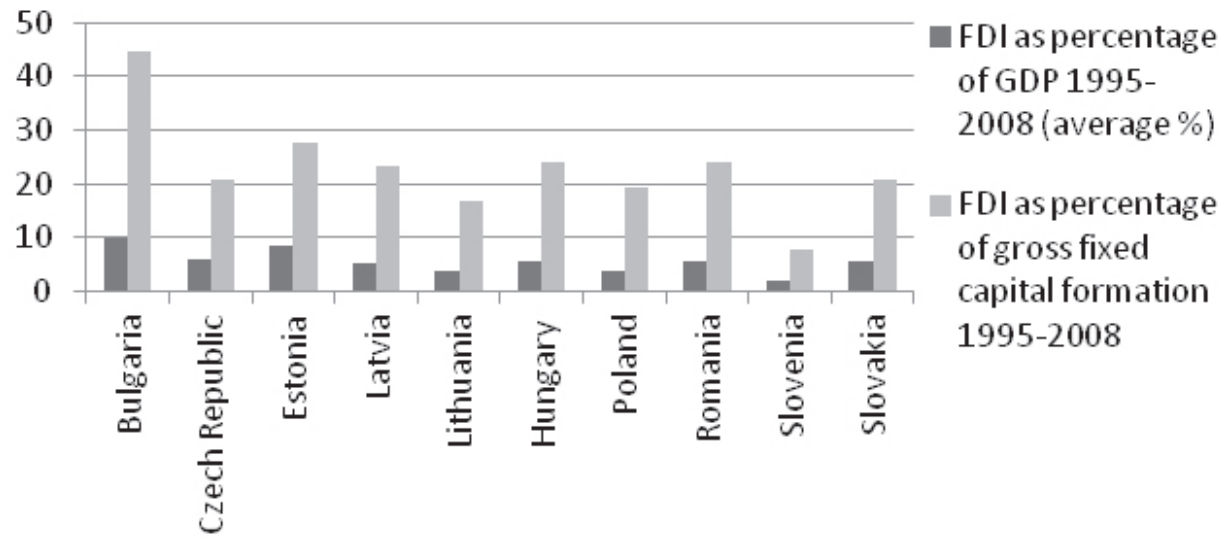

Source: Eurostat, 2015; 2016

The above-discussed lower wages than productivity is a factor that coincides with intensive inflow of FDI in Bulgaria, Romania and Slovakia. Other factors, probably higher technology level, seem to underpin FDI inflows in Estonia, the Czech Republic and Hungary, where labor cost advantages were not so substantial (Lissowska, 2014). 


\subsection{Export}

The growth of consumption and investments have boosted import in the CEE countries. They were not balanced with export which created additional source of vulnerability through current account deficits (Fig. 10). Only Slovenia and the Czech Republic, due to stable export, escaped high imbalances of current accounts.

Figure 10. Balance of the current accounts of CEE countries, \% of GDP, 2002-2013 average

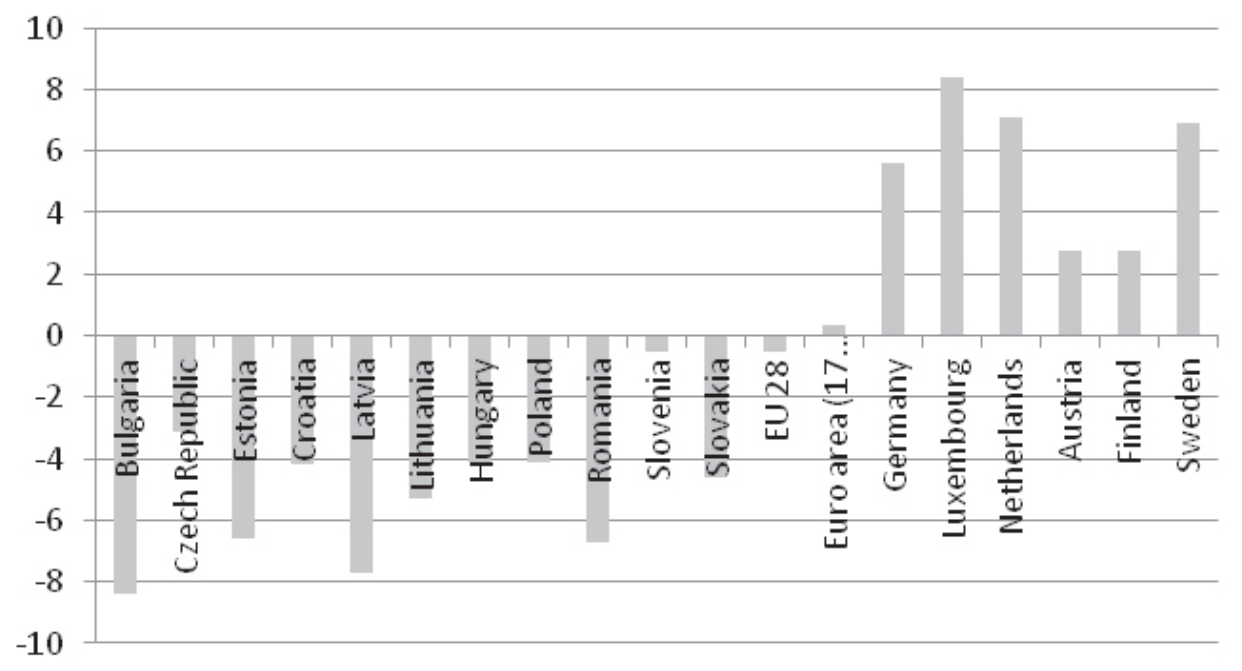

Source: Eurostat, n.d.

We need to look at the trade balance of the CEE countries in the context of the EU. The trade balance of the Union is a result of the countries that traditionally achieve trade surplus: Germany, Luxemburg, Austria, Finland, Sweden, and the Netherlands. Countries that traditionally attain trade deficit include Greece, Portugal, Spain, Latvia, Portugal and most of the CEE countries as indicated in Figure 10. We believe that this situation is a result of the structural imbalances of the Union. It is an illusion to expect that the EU will sustain its current position as a leading trade player as well as major net exporter. The EU is gradually losing the leading position in the world trade. Thus, according to Eurostat database, the share in world trade in goods decreased from 17.9 per cent in 2004 to 14.8 per cent in 2014.

The reason for achieving trade surpluses for the abovementioned countries is mainly due to the use of deflatory policies - such as keeping the nominal wages 
below productivity level. Still, there are limits to this kind of deflationary policies known as beggar-thy-neighbor policies, which negatively affect countries within the EU with trade deficit and also countries outside the EU. A small country (such as Luxembourg) can run current account surpluses over extended periods of time without having a perceptible impact on its trading partners. A large country (such as Germany) is unlikely to have indefinitely large current account surpluses. The reason for this is that Germany's current account surplus is the current account deficit of its partners, such as Italy. Thus, in case of monetary union, running current account surpluses is possible if the same attempts fail in some other euro area countries.

The policy of Germany for keeping low wages is destructive for the rest of the Member States and it puts pressure on other Member States to keep wages low. In addition, the beggar-thy-neighbor policy is self-defeating because it implies accumulation of the foreign debt of those countries with persistent trade deficits. Once it is acknowledged that the debt is unsustainable, growth in countries with persistent trade surpluses would inevitably flag as well. Moreover, the creditor countries would have to write off chunks of their 'bad assets' (Laski \& Podkaminer, 2012, p. 458). In other words, the world economy overall is a closed system and effects of net export offset each other. This is particularly relevant for the EU, which consists of many small economies, but overall is a relatively closed large economy. Individual EU Member States can grow by means of wage restraints but in the EU overall such a policy would have negative effects.

\section{Policy recommendations}

The positive aspects of the current model in the CEE countries was to a larger degree related to improvements in structural supply-side factors such as productivity, innovation, competitiveness, etc. On the other hand, the crisis showed the negative aspects of the growth model: the growth patterns were interrupted and the convergence process slowed down due to the sudden stop of foreign capital. Before the crisis, in the CEE countries, the suppressed domestic demand resulted in increase of private debt in order to maintain consumption levels. Consumption growth and increased investments boosted the import in the majority of the CEE countries, but were not counterbalanced with export, which created additional source of vulnerability through current account deficits.

Instead of abandoning this model that proved to be ineffective and highly risky, low wage competitiveness model has been reinforced by the EU. Given that 
CEE growth cannot be disentangled from that of the EU as a whole, the question is how to re-shape the model of growth that would stimulate growth in the CEE.

One direction of possible policy measures is targeting the supply side. Among the important factors, one should mention further advances in competitiveness and in fostering productivity and innovation, factors that did contribute to higher growth in these economies and which are likely to continue to have such an effect, if conditions are in place. A change towards investment-led innovation based growth model with higher value added is needed. This can be achieved through:

1) Medium- to long-term consensus on aligning the dynamics of workers' pay with that of labor productivity, or in other words increase of the real wages;

2) Closing the productivity gaps with the EU. Four major domestic sectors: construction, transportation, retail, and "network" industries such as railway, postal, electric, and telecom systems are identified by Labaye et al. (2013, p. 7). It is also urgent that countries in the region need to reform pension systems, change migration policy, and find incentives to attract talent to the region. Closing the gap with the rest of the EU in educational attainment levels and improving education quality might significantly soften the constraints imposed by the demographic threats and produce sizable returns in terms of additional income convergence (Cuaresma et al., 2012);

3) Use of the instruments of monetary and exchange rate policy, as most of the CEE countries are not members of the euro zone (in practice, only Poland used these instruments in 2009). Being still a "club on their own" (Dobrinsky \& Havlik, 2014, p. 22), there may also exist lines of policymaking that are specific to this group of countries.

4) Fostering innovation can be achieved by attraction of FDIs and return to pre-crisis rates. Attracting FDIs needs to be continued. For Central European countries (the Czech Republic, Hungary, Poland and Slovakia) the participation in German supply chain cluster led to technology transfer and accelerated income convergence while simultaneously increasing the exposure to fluctuations of final demand outside Europe (IMF, 2013). In addition, further developing the institutional basis for fostering innovation activities should be given a privileged treatment such as measures to improve the business environment, the government quality and spending efficiency. This is more the case since the recent crisis has led to a divergent trend in innovation spending within the EU (Cuaresma et al., 2012). 
Regarding the demand site, we believe that strong demand is a prerequisite for higher economic growth. In order to foster competitiveness, the nominalwage growth should evolve in line with labor-productivity growth in each of the Member States. This is one of the measures that we believe will allow fair and real productivity-wage levels and fair policies of the Member States of the Union. The Euro-Plus Pact and the Six-Pack regulations, drafted in November, propose wage flexibility, and most often wage flexibility is a code word for wage moderation. These measures seem to suggest that the wages should increase in all European countries, but only in those who have wages below productivity level. Those countries who let unit labor costs rise too fast are equally responsible for the macroeconomic imbalances as those who gained market shares through wage restraint (Hoffer \& Spiecker, 2011).

Onaran and Galanis (2012, p. 40) have found that if all wage-led countries like the countries from the EU return to their previous peak wage share levels as in the late 1970s global GDP would increase by 3.05 per cent. According to Onaran (2015), due to the global race to the bottom in the wage share, most of the positive effects on net export are wiped out as unit labor cost falls simultaneously in all countries, and their international competitiveness relative to each other does not change significantly. In addition, Storm and Naastepad (2012) conclude that a reasonable order of magnitude is that a one percentage point increase in real wage growth leads to a 0.38 percentage point increase in labor productivity growth. Higher real wage growth induces firms to increase labor productivity in order to protect their profitability. Hence, the available evidence suggests that real wage growth has a positive long-run effect on labor productivity growth and increase of the net export. This is important for economic policy as it suggests that excessive wage constraint is likely to lead to weak productivity performance. The problem that may arise from the increase of the wages is the inflationary effect. But it is also an advantage since the EU is at the edge of deflation. Therefore, the increase of the wages will only help to reach the 2 per cent inflation target of the European Central Bank, and at the same it could stimulate new jobs and economic growth. 


\section{Conclusion}

GDP growth is below potential in the CEE countries, and convergence towards Western European counties has run out of steam. Austerity and risk avoidance by banks resulted in low investment activity. FDIs are showing a longer-term downward trend and the share of the FDI in the total investments is also slowing down. A new growth model that will stimulate investments is needed. The CEE countries need to abandon low wage competitiveness model, since empirical analysis proves that CEE countries did fare better than Western European economies on this account during the past two decades, as structural supplyside factors played a greater role in the CEE growth model. Wage adjusted productivity in manufacturing for CEEs is substantially higher than EU-15 and this 'productivity reserve' leaves room for upward wage convergence.

Still, the main adjustment tool in the crisis management strategy has been wage reduction for most of the CEE countries. The policy of internal devaluation is pushed by direct intervention into wage development by cutting and freezing public sector and minimum wages, for example in Hungary, Latvia and Romania. Also there are structural reforms of wage setting institutions to increase downward flexibility of wages such as New European Economic Governance; European Semester and European Imbalances procedure for setting the balance in the balance of payments. We believe these policies are not addressing the real cause but are creating harmful side-effects which may cause double-dip recession.

Even though the wages are both a source of demand and a cost factor, this dual role of wages as both a source of demand and a cost of production when put in integrated macroeconomic model can have different effects. Typically, there is positive effect of the wage share on consumption, a negative effect on investment and a negative net export effect. The precise magnitude of these effects depends on the institutional setting in each country and on the degree of openness of the economy (Onaran \& Galanis, 2012).

Empirical data show that wages were more clearly aligned to productivity in countries such as the USA or the UK (i.e. there was less wage moderation through holding wage growth below productivity growth). Yet in a longer run, in recent decades these countries report much better employment performance and higher productivity growth than Germany, where wage growth was held below productivity growth for a substantial period. It also needs to be remembered that even in economic theory, innovation itself is endogenous, and excessive 
wage moderation may reduce innovation activity, resulting in lower productivity growth in the long run (Meager \& Speckasser, 2011).

Since we cannot separate the model of the CEE from the EU, we believe that the EU needs to overcome the coordination problem of implementation of the macroeconomic policies by institutional building at national as well as the European level. It is crucial that policies for increasing the wages are part of a broad mix of economic policies in order to achieve sustainable and balanced growth between the EU countries followed by full employment.

Elena Makrevska Disoska, $\mathrm{PhD}$, is engaged as a teaching assistant at the Department of International Trade, Faculty of Economics, University Ss. Cyril and Methodius in Skopje. Disoska's professional fields of work are macroeconomics, international economics and European economic integration. So far she has been engaged in many projects and has participated in international and domestic workshops and scientific conferences.

\section{References}

Barro, J. R. \& Sala-i-Martin, X. (1995), Technological Diffusion, Convergence and Growth, NBER Working paper 116, Cambridge: National Bureau of Economic Research.

Becker, T.; Daianu, D.; Darvas, Z.; Gligorov, V.; Landesmann, M.; Petrovic, P.; Pisani-Ferry, J.; Rosati, D.; Sapir, A. \& Di Mauro, B. W. (2010), Whither growth in central and eastern Europe? Policy lessons for an integrated Europe, Brugel Blue Print Series, vol. 11. Retrieved from http://www.bruegel.org/publications/ publication-detail/publication/453-whither-growth-in-central-and-eastern-europepolicy-lessons-for-an-integrated-europe/ [accessed 1 Aug 2016]

Bhaduri, A. \& Marglin, S. (1990), 'Unemployment and the real wage,' Cambridge Journal of Economics, vol. 14, pp. 375-393.

Burgess, R. \& Körner, K. (2012), Western Balkans: Bumps on the Road of EU Accession, Deutsche Bank Research Papers, Frankfurt am Main: Deutsche Bank.

Cuaresma, J. C.; Oberhofer, H.; Smits, K. \& Vincelette, G. A. (2012), The World Bank Policy Research, Working Paper 6185, Washington, DC: The World Bank.

Cynamon, Z. B. \& Fazzari, M. S. (2015), 'Inequality, the Great Recession, and Slow Recovery,' Cambridge Journal of Economics, vol. 40, no. 2, pp. 373-399. http:// dx.doi.org/10.1093/cje/bev016

Dobrinsky, R. \& Havlik, P. (2014), Economic Convergence and Structural Change: the Role of Transition and EU Accession, Vienna Institute for International 
Economic Studies Papers, Research report no. 395. Retrieved from http://wiiw. ac.at/economic-convergence-and-structural-change-the-role-of-transition-and-euaccession-dlp-3357.pdf [accessed 1 Aug 2016]

EBRD (2013), Transition report 2013: Stuck in transition, London: European Bank for Reconstruction and Development.

EC (2010), Europe 2020: A strategy for smart, sustainable and inclusive growth, EU-Communication from the Commission, COM (2010) 2020 final, 3.3.2010.

— (2013), European Competitiveness Report 2013: Toward Knowledge Driven Reindustrialization, Commission Staff Working Document, SWD (2013) 347 final, Brussels: European Commission.

Eurostat (n.d.), 'Balance of the current account, \% of GDP,' Eurostat Database. Retrieved from http://ec.europa.eu/eurostat/tgm/table.do?tab=table\&language= en\&pcode=tec00043 [accessed 1 Aug 2016]

(2015), 'Balance of payments by country,' Eurostat Database. Retrieved from http://appsso.eurostat.ec.europa.eu/nui/show.do?dataset=bop_q_c\&lang=en [accessed 1 Aug 2016]

(2016), 'GDP and main components: current prices,' Eurostat Database.

Retrieved from http://appsso.eurostat.ec.europa.eu/nui/show.do?dataset=nama gdp_c\&lang=en [accessed 1 Aug 2014]

IMF (2013), German-Central European Supply Chain-Cluster Report, Washington, DC: International Monetary Fund. Retrieved from https:/www.imf.org/external/ pubs/ft/scr/2013/cr13263.pdf [accessed 1 Aug 2016]

Labaye, E.; Sjåtil, P. E.; Bogdan, W.; Novak, J.; Mischke J.; Fruk, M. \& Ionuţiu, O. (2013), A New Dawn: Reigniting Growth in Central and Eastern Europe, London: McKinsey Global Institute Europe.

Laski, K. \& Podkaminer, L. (2012), 'The basic paradigms of EU economic policymaking need to be changed,' Cambridge Journal of Economics, vol. 36, pp. 253-270. http://dx.doi.org/10.1093/cje/ber030

Lavoie, M. \& Stockhammer, E. (2015), Wage-Led Growth: Concept, Theories and Policies, ILO Working Papers, no. 41, Geneva: International Labor Organization. Retrieved from http://www.ilo.org/wcmsp5/groups/public/---ed_protect/--protrav/---travail/documents/publication/wcms_192507.pdf [accessed 1 Aug 2016]

Leitner, S. \& Römisch, R. (2015), Economic and Social Convergence in the EU: A Policy Note, Grincon Working Paper Series, no. 113. Retrieved from http:// www.grincoh.eu/media/serie_1_growth_structural_change_deve/grincoh_ wp1.13_leitner_rmisch.pdf [accessed 1 Aug 2016]

Lissowska, M. (2014), 'Welfare against growth gains in post-transition countries: what are the consequences for stability?' Economics, vol. 8, p. 16. 
Marzinotto, B. (2012), The Growth Effects of EU Cohesion Policy: A Meta-Analysis, Bruegel Working Paper, no. 14, pp. 8-12.

Onaran, O. \& Galanis, G. (2015), Is Aggregate Demand Wage-Led or Profit-Led? International Labor Working Papers, no. 40, Geneva: International Labor Organization. Retrieved from http://www.ilo.org/wcmsp5/groups/public/---ed_ protect/---protrav/---travail/documents/publication/wcms_192121.pdf [accessed 1 Aug 2016]

Panagiotou, R. (2012), The Impact of the Economic Crisis on the Western Balkans and Their Accession Prospects, European University Institute Working Papers, no. 64, Florence: European University Institute.

Podkaminer, L. (2013), Development Pattern of Central and Eastern European Countries, Research Report 388, Vienna: The Vienna Institute for International Economic Studies.

Popescu, H. G. (2014), 'FDI and economic growth in Central and Eastern Europe,' Sustainability, vol. 6, no. 11, pp. 8149-8163. http://dx.doi.org/10.3390/su6118149

Tridico, P. (2012), 'Financial Crisis and Global Imbalances: Its Labour Market Origins and the Aftermath,' Cambridge Journal of Economics, vol. 36, pp. 17-42.

http://dx.doi.org/10.1093/cje/ber01 